\title{
Pengaruh Kualitas Pelayanan Fiskus, Pemahaman Peraturan Perpajakan Dan Penerapan Sistem E-Filling Terhadap Kepatuhan Wajib Pajak: Sosialisasi Perpajakan Sebagai Pemoderasi
}

\author{
${ }^{1 *}$ Devi Safitri, ${ }^{2}$ Sem Paulus Silalahi \\ ${ }^{1,2}$ Ekonomi dan Bisnis, Universitas Riau, Indonesia \\ *Email korenpondensi: devi_fadly@yahoo.co.id
}

\begin{abstract}
This research is aimed to examine empirically effect of fiscus service quality, tax regulation comprehension, and e-filing system implementation on Small Medium Enterprises (SMEs) Personal Taxpayer obedience, with taxation socialization as moderating variable. Research samples are Personal SMEs registered in Tax Service Office (Kantor Pelayanan Pajak) Pratama Pekanbaru Senapelan. Sampling method uses purposive sampling, and sample size measured by Slovin formula. Analysis method uses Multiple Regression Analysis and Moderated Regression Analysis (MRA). Result of research shows that fiscus service quality and e-filing system implementation have no effect on taxpayer obedience partially, while tax regulation comprehension has significant effect on taxpayer obedience. Further, taxation socialization is failed to moderates the effect of fiscus service quality on taxpayer obedience. Taxation socialization is failed as well to moderates the effect of tax regulation comprehension on taxpayer obedience, and taxation socialization is failed to moderates the effect of and e-filing system implementation on taxpayer obedience.
\end{abstract}

Keywords: E-filling Implementation, Fiscus Service Quality, Taxpayer Obedience, Tax Regulation Comprehension.

Saran sitasi: Safitri, D., \& Silalahi, S. P. (2020). Pengaruh Kualitas Pelayanan Fiskus, Pemahaman Peraturan Perpajakan Dan Penerapan Sistem E-Filling Terhadap Kepatuhan Wajib Pajak: Sosialisasi Perpajakan Sebagai Pemoderasi. Jurnal Akuntansi dan Pajak, 20(2), 145-153. doi: http://dx.doi.org/10.29040/jap.v20i2.688

DOI: http://dx.doi.org/10.29040/jap.v20i2.688

\section{Pendahuluan}

Kepatuhan wajib pajak merupakan salah satu masalah dari penerapan self assessment system. Menurut Resmi (2017:11), self assessment system merupakan sistem pemungutan pajak yang memberi wewenang Wajib Pajak dalam menentukan sendiri jumlah pajak yang terutang setiap tahunnya sesuai dengan peraturan perundang - undangan perpajakan yang berlaku. Wajib Pajak diberi kepercayaan untuk menghitung, membayar, melaporkan, dan mempertanggungjawabkan pajak terutangnya. Jadi, berhasil atau tidaknya pelaksanaan pemungutan pajak sebagian besar tergantung dari Wajib Pajak Sendiri. Oleh karena itu, keberhasilan self assessment system sangat ditentukan oleh tinggi rendahnya tingkat kepatuhan dari si wajib pajak.

Berdasarkan data Laporan Kinerja Pajak yang mencakup seluruh penerimaan pajak di Indonesia, maka diperoleh capaian persentase realisasi penerimaan pajak selama empat tahun terakhir adalah sebagai berikut:

Tabel 1 Persentase Realisasi Penerimaan Pajak Indonesia

(dalam triliun rupiah)

\begin{tabular}{lcccc}
\hline Tahun & $\mathbf{2 0 1 3}$ & $\mathbf{2 0 1 4}$ & $\mathbf{2 0 1 5}$ & $\mathbf{2 0 1 6}$ \\
\hline Target & 995,21 & $1.072,37$ & $1.294,26$ & $1.355,20$ \\
Realisasi & 921,27 & 981,83 & $1.060,83$ & $1.105,81$ \\
Capaian & $92,57 \%$ & $91,56 \%$ & $81,96 \%$ & $81,60 \%$ \\
\hline
\end{tabular}

Sumber: Laporan Kinerja Direktorat Jenderal Pajak (2017)

Berdasarkan Tabel 1 diatas, tingkat capaian penerimaan pajak tahun 2013 s/d 2016 terus terjadi penurunan, artinya Indonesia mengalami penurunan penerimaan pajak selama empat tahun terakhir ini. Hal ini menandakan hilangnya potensi penerimaan negara yang dapat digunakan sebagai sumber 


\section{Jurnal Akuntansi dan Pajak, 20(02), 2019, 146}

pembiayaan belanja sosial dan pembangunan infrastruktur.

Rendahnya penerimaan pajak berhubungan dengan kepatuhan wajib pajak. Isu terkait kepatuhan sangat penting karena ketidakpatuhan secara bersamaan dapat memicu upaya menghindari pajak yang menyebabkan berkurangnya penerimaan pajak. Semakin benar tingkat penghitungan, penyetoran, serta penyampaian pajak, maka semakin tinggi pula tingkat kepatuhan terhadap aturan pajak dalam pelaksanaan pemenuhan kewajiban pajaknya (Rahayu, 2017:20).

Berikut ini tingkat kepatuhan Wajib Pajak Usaha Mikro Kecil Menengah (UMKM) Orang Pribadi di Kantor Pelayanan Pajak (KPP) Pratama Pekanbaru Senapelan dalam melaporkan Surat Pemberitahuan (SPT) adalah sebagai berikut:

Tabel 2 Tingkat Kepatuhan Wajib Pajak

\begin{tabular}{cccc}
\hline Tahun & $\begin{array}{c}\text { Jumlah WP } \\
\text { Terdaftar }\end{array}$ & $\begin{array}{c}\text { Lapor SPT } \\
\text { Tahunan }\end{array}$ & $\begin{array}{c}\text { Persentase } \\
\text { Kepatuhan }\end{array}$ \\
\hline $\mathbf{2 0 1 4}$ & 783 & 702 & $89,65 \%$ \\
$\mathbf{2 0 1 5}$ & 2.799 & 2.069 & $73,91 \%$ \\
$\mathbf{2 0 1 6}$ & 3.650 & 2.545 & $69,72 \%$ \\
$\mathbf{2 0 1 7}$ & 4.664 & 2.910 & $62,39 \%$ \\
\hline
\end{tabular}

Sumber: Kantor Pelayanan Pajak (KPP) Pratama Pekanbaru Senapelan (2017)

Dari Tabel 2 diatas, menunjukkan bahwa jumlah wajib pajak terdaftar dari tahun 2014 sampai 2017 mengalami kenaikan setiap tahunnya, namun jumlah SPT Tahunan yang dilaporkan oleh wajib pajak tidak sebanding dengan jumlah wajib pajak yang terdaftar. Sehingga tingkat persentase kepatuhan dari wajib pajak terus mengalami penurunan yang cukup signifikan sebesar $62,39 \%$ di tahun 2017. Dari fenomena tersebut, maka dapat disimpulkan bahwa masih kurangnya kepatuhan dalam melaporkan SPT bagi pelaku Orang Pribadi UMKM di KPP Pratama Pekanbaru Senapelan.

Banyaknya unit UMKM di Indonesia juga harus tercermin dalam penerimaan pajak. Namun kenyataannya masih ada wajib pajak UMKM yang tidak patuh. Bagi pelaku UMKM, pajak masih dilihat sebagai beban, yang sebisa mungkin harus dihindari. Pemerintah Indonesia perlu memperhatikan sektor UMKM secara serius. Peranan UMKM dalam perekonomian patut diperhitungkan dalam proses merencanakan suatu kebijakan di bidang perpajakan. Banyaknya pelaku usaha UMKM bila diperhatikan secara seksama merupakan potensi yang akan berdampak pada peningkatan perilaku kepatuhan pajak (Fuadi \& Mangoting, 2013:20).

Kepatuhan Perpajakan didefinisikan sebagai sebagai situasi di mana wajib pajak memenuhi semua kewajiban pajak dan menerapkan hak pajaknya (Dwikora, 2013:67). Untuk mengetahui wajib pajak patuh bisa diukur dari pemahaman terhadap semua ketentuan peraturan perundangundangan perpajakan, mengisi formulir dengan lengkap dan jelas, menghitung jumlah pajak yang terutang dengan benar, membayar dan melaporkan pajak yang terutang tepat pada waktunya (Adiasa, 2013). Maka konteks kepatuhan dalam penelitian ini mengandung arti bahwa Wajib Pajak berusaha untuk mematuhi peraturan hukum perpajakan yang berlaku, baik memenuhi kewajiban ataupun melaksanakan hak perpajakannya.

Tinggi rendahnya kepatuhan wajib pajak dapat dipengaruhi beberapa faktor, salah satunya adalah kualitas pelayanan fiskus. Supadmi (2009:3) mengatakan bahwa salah satu upaya dalam meningkatkan kepatuhan wajib pajak adalah memberikan pelayanan yang baik kepada wajib pajak. Pelayanan fiskus merupakan suatu sikap atau perbuatan petugas pajak untuk membatu wajib pajak dalam melaksanakan kewajiban pajakanya (Jatmiko, 2006). Petugas pajak dikatakan berkualitas apabila petugas pajak memberikan informasi yang akurat mengenai perpajakan termasuk tata cara perhitungan, penyetoran, dan pelaporannya serta tidak melakukan tindakan pidana yang melanggar aturan dan SOP yang berlaku. Peningkatan kualitas pelayanan pajak diharapkan dapat meningkatkan kepuasan kepada wajib pajak sehingga meningkatkan kepatuhan dalam bidang perpajakan. Penelitian dilakukan oleh Fuadi \& Mangoting (2013) dan Prajogo \& Widuri (2013) menemukan bahwa kualitas pelayanan fiskus berpengaruh positif terhadap kepatuhan wajib pajak. Namun lain halnya dengan hasil penelitian yang dilakukan oleh Masruroh \& Zulaikha (2013) menemukan bahwa kualitas pelayanan fiskus tidak memiliki pengaruh terhadap kepatuhan wajib pajak.

Selain faktor kualitas pelayanan fiskus, pemahaman peraturan perpajakan dapat meningkatkan kepatuhan wajib pajak. Prajogo \& Widuri (2013) menyatakan bahwa tingkat pemahaman adalah upaya untuk meningkatkan pengetahuan secara mendalam yang dilakukan oleh seseorang dan sejauh mana ia mampu memahami dengan benar akan suatu permasalahan yang ingin 


\section{Jurnal Akuntansi dan Pajak, 20(02), 2019, 147}

diketahui. Sedangkan menurut Hardiningsih (2011) dalam (Adiasa, 2013:346), pemahaman peraturan perpajakan adalah cara wajib pajak dalam memahami peraturan perpajakan yang telah ada. Sudah seharusnya wajib pajak haruslah menguasai peraturan serta kewajiban yang dijalankannya agar terhindar dari sanksi-sanksi yang berlaku. Dengan demikian pemahaman tentang perpajakan berupa informasi perpajakan dan peraturan perpajakan akan meningkatkan kepatuhan seseorang dalam memenuhi kewajiban perpajakannya. Penelitian ini didukung oleh Prajogo \& Widuri (2013) yang berhasil membuktikan bahwa pemahaman peraturan perpajakan mempunyai pengaruh terhadap kepatuhan wajib pajak. Namun lain halnya penelitian Arisandy (2017) menemukan bahwa pemahaman tentang peraturan perpajakan tidak memiliki pengaruh terhadap kepatuhan wajib pajak.

Selanjutnya faktor yang mempengaruhi kepatuhan wajib pajak adalah penerapan sistem $e$ filing. Demi mencapai tingkat kepatuhan wajib pajak, Pemerintah sudah mengatur dan menetapkan cara cepat untuk meyampaikan laporan pajak agar memudahkan wajib pajak dalam penyampaian SPT. Salah satu upaya pemerintah yang dilakukan oleh Dirjen Pajak adalah dengan menerbitkan Keputusan Dirjen Pajak No. Kep-88/PJ/2004 yang dikeluarkan pada 21 Mei 2004 secara resmi meluncurkan suatu produk yakni e-filing atau electronic filing system. E-filing dalam PER 01 / PJ / 2014 menjelaskan metode pengiriman surat pemberitahuan tahunan, yang dilakukan secara elektronik online dan real time dengan internet di situs web Direktorat Jenderal Pajak (Suherman et al, 2015). E-filing merupakan bagian dari reformasi administrasi perpajakan dengan tujuan memudahkan dalam membuat dan menyampaikan laporan SPT kepada DJP. Dengan diterapkannya sistem ini, dapat memberikan kepuasan dan kenyamanan kepada wajib pajak sehingga meningkatkan kepatuhan wajib pajak (Husnurrosyidah \& Suhadi, 2017:99). Penelitian yang dilakukan oleh (Susmita \& Supadmi, 2016) menemukan bahwa penerapan e-filing memiliki pengaruh positif terhadap kepatuhan wajib pajak. Namun berbeda dengan penelitian yang dilakukan oleh Suherman et al. (2015) yang menemukan hasil bahwa penerapan $e$-filing tidak memiliki pengaruh terhadap kepatuhan wajib pajak.

Sedangkan variabel moderating dalam penelitian ini adalah adalah Sosialisasi Perpajakan. Sosialisasi perpajakan adalah cara DJP kepada wajib pajak untuk memberikan kesadaran, pemahaman dan penyuluhan tentang aturan perpajakan yang berlaku. Bentuk dari sosialisasi ini adalah melalui media komunikasi, baik media cetak seperti surat kabar, majalah maupun media audio visual seperti radio atau televisi (Sulistianingrum, 2009 dalam Dharma \& Suardana, 2014). Megawangi \& Setiawan (2017) menemukan bahwa sosialisasi perpajakan mampu memperkuat hubungan kualitas pelayanan dengan kepatuhan Wajib Pajak Badan. Namun lain halnya dengan penelitian Handayani \& Tambun (2016) yang hasil penelitiannya menyatakan bahwa sosialisasi perpajakan tidak mampu memoderasi pengaruh antara kualitas pelayanan dengan kepatuhan Wajib Pajak Badan.

Penelitian ini merupakan pengembangan penelitian Megawangi \& Setiawan (2017). Peneliti menambah variabel pemahaman peraturan perpajakan dan penerapan sistem e-filling karena kedua variabel tersebut diduga merupakan faktor penentu untuk meningkatkan kepatuhan wajib pajak. Penelitian ini diharapkan memberikan kontribusi dalam menemukan faktor - faktor lain yang mempengaruhi kepatuhan wajib pajak dan dengan adanya variabel moderasi yaitu sosialiasasi perpajakan, apakah dapat memperkuat pengaruh antara kualitas pelayanan fiskus, pemahaman peraturan perpajakan dan penerapan sistem $e$-filling terhadap kepatuhan wajib pajak.

Kepatuhan Perpajakan didefinisikan sebagai sebagai situasi di mana wajib pajak memenuhi semua kewajiban pajak dan menerapkan hak pajaknya (Dwikora, 2013:67). Berdasarkan Pasal 3 Peraturan Menteri Keuangan RI No. 39/PMK.03/2018 tentang Tata Cara Pengembalian Pendahuluan Kelebihan Pembayaran Pajak, Wajib Pajak kriteria tertentu yang dapat diberikan Pengembalian Pendahuluan terhadap kelebihan pembayaran Pajak Penghasilan maupun Pajak Pertambahan Nilai adalah Wajib Pajak patuh dengan memenuhi 4 (empat) kriteria, yakni: 1) tepat waktu dalam menyampaikan SPT; 2) tidak mempunyai tunggakan pajak untuk semua jenis pajak, kecuali tunggakan pajak yang telah memperoleh izin mengangsur atau menunda pembayaran pajak; 3) laporan keuangan diaudit oleh akuntan publik atau lembaga pengawasan keuangan pemerintah dengan pendapat wajar tanpa pengecualian selama 3 (tiga) tahun berturut-turut; dan 4) tidak pernah dipidana karena melakukan tindak pidana di bidang perpajakan berdasarkan putusan pengadilan yang 


\section{Jurnal Akuntansi dan Pajak, 20(02), 2019, 148}

telah mempunyai kekuatan hukum tetap dalam jangka waktu 5 (lima) tahun terakhir.

Parasuraman et al. (1985) dalam Megawangi \& Setiawan (2017) menjelaskan kualitas pelayanan merupakan pengukuran seseorang terhadap perbandingan kinerja sesungguhnya dari penyedia layanan dengan yang diharapkan. Sehingga apabila wajib pajak merasa puas terhadap pelayanan fiskus akan mendorong wajib pajak untuk patuh dan mau melaksanakan kewajiban perpajaknnya (Siregar et al., 2012:3).

Pemahaman peraturan perpajakan merupakan cara wajib pajak untuk mengetahui, memahami dan menerapkannya dalam membayar pajak (Resmi, 2012:49). Pemahaman peraturan perpajakan juga cara atau mekanisme wajib pajak memahami ketentuan dan peraturan perpajakan yang ada serta mengaplikasikannya seperti, menghitung, menyetor, dan melaporkan pajak. Apabila setiap wajib pajak paham dan mengerti hal tersebut, tentunya akan terjadi peningkatan kepatuhan pada wajib pajak (Adiasa, 2013:34).

Dalam hal peningkatan kepatuhan wajib pajak, Dirjen pajak mengeluarkan sistem untuk mempermudah wajib pajak dalam melakukan kewajiban melaporkan SPT tahunan yaitu sistem $e$ filling. E-filling merupakan suatu sistem elektronik yang digunakan untuk menyampaikan Surat Pemberitahuan Tahunan (SPT) dengan memanfaatkan sistem online dan real time serta melalui sebuah penyedia jasa aplikasi yang sudah bekerja sama dengan Direktorat Jendral Pajak (Erawati \& Ratnasari, 2018).

Menurut Rahayu \& Suhayati, 2010:28), untuk memaksimalkan penerimaan negara, salah satu cara penting yang harus dilaksanakan pemerintah adalah memberikan pelayanan prima dan berkualitas. Tujuannya adalah untuk meningkatkan kepatuhan wajib pajak, kepercayaan terhadap administrasi perpajakan, dan produktivitas petugas pajak. Semakin baik kualitas pelayanan pajak akan menghasilkan rasa puas dan mendorong wajib pajak untuk patuh melaksanakan kewajiban pajaknya. Sehingga hal ini mendasari dugaan bahwa kualitas pelayanan fiskus berpengaruh positif terhadap kepatuhan wajib pajak. Hasil penelitian Fuadi \& Mangoting (2013) dan Megawangi \& Setiawan (2017) menemukan adanya pengaruh positf antara kualitas pelayanan fiskus dengan kepatuhan wajib pajak. Berdasarkan penjelasan di atas, maka peneliti mengajukan hipotesis berikut:
$H_{l}$ :Kualitas Pelayanan Fiskus berpengaruh positif terhadap kepatuhan wajib pajak.

Menurut Adiasa (2013:27), pemahaman peraturan perpajakan adalah cara yang dilakukan wajib pajak untuk memahami peraturan dan undangundang, serta prosedur pajak, dan mengaplikasikannya. Terpenuhinya kewajiban perpajakan dengan baik apabila si wajib pajak paham dan mnengerti mengenai aturan pajak yang ada. Namun apabila wajib pajak tidak paham akan aturan perpajakan yang berlaku akan mendorong wajib pajak menjadi tidak patuh. Sehingga hal ini mendasari dugaan bahwa pemahaman wajib pajak tentang peraturan perpajakan berpengaruh positif terhadap kepatuhan wajib pajak. Adiasa (2013), Suryadi \& Sunarti (2016), dan Prajogo \& Widuri (2013) membuktikan bahwa adanya hubungan positif antara pemahaman peraturan perpajakan dengan kepatuhan wajib pajak. Dari uraian diatas, maka peneliti mengajukan hipotesis berikut:

$\mathrm{H}_{2}$ :Pemahaman peraturan perpajakan berpengaruh positif terhadap kepatuhan wajib pajak.

E-filing merupakan suatu proses terintegrasi dan realtime dengan menggunakan Application Service Provider (ASP) yang telah ditunjuk oleh DJP untuk melaporkan SPT secara elektronik dalam bentuk data digital. Pelaksanaan $e$-filing ini sebagai salah satu upaya DJP dalam modernisasi sistem administrasi perpajakan di Indonesia, tujuannya adalah untuk memudahkan, menyederhanakan dan meningkatkan pelayanan sehingga wajib pajak merasa puas. Apabila wajib pajak memanfaatkan penggunaan sistem $e$-filling ini dalam melaksanakan kewajiban pajaknya, maka akan meningkatkan kepatuhan bagi wajib pajak dalan melaporkan SPTnya. Hasil penelitian Agustiningsih (2016), Susmita \& Supadmi (2016), dan Husnurrosyidah \& Suhadi (2017) menyatakan bahwa terdapat pengaruh positif penerapan sistem $e$-filing terhadap kepatuhan wajib pajak. Berdasarkan uraian diatas, maka dapat dirumuskan hipotesis sebagai berikut :

$\mathrm{H}_{3} \quad$ :Penerapan sistem e-filing berpengaruh positif terhadap kepatuhan wajib pajak.

Menurut Prajogo \& Widuri (2013), pengukuran kualitas pelayanan yaitu kompetensi yang dimiliki aparat pajak dalam memberikan pelayanan memuaskan, pelayanan dengan tanggapan, sopan, dan dipercaya Pemerintah harus memastikan bahwa kualitas pelayanan yang diberikan sudah baik dan terus ditingkatkan dengan cara mengadakan 


\section{Jurnal Akuntansi dan Pajak, 20(02), 2019, 149}

pelatihan tentang perpajakan dan bagaimana meningkatkan kualitas pelayanan. Pelayanan dikatakan berkualitas apabila dapat memberikan rasa aman, nyaman, lancar, dan kepastian hokum kepada wajib pajak.

Sedangkan Sosialisasi perpajakan adalah upaya yang dilakukan oleh Dirjen Pajak untuk memberikan sebuah pengetahuan kepada masyarakat dan khususnya wajib pajak agar mengetahui tentang segala hal mengenai perpajakan baik peraturan maupun tata cara perpajakan melalui metode-metode yang tepat. Dengan adanya sosialisasi perpajakan, diharapkan akan memperkuat hubungan antara kualitas pelayanan fiskus terhadap kepatuhan wajib pajak. Hasil penelitian yang dilakukan oleh Megawangi \& Setiawan (2017) menyatakan bahwa sosialisasi perpajakan mampu memoderasi pengaruh kualitas pelayanan pada kepatuhan Wajib Pajak Badan. Dari uraian diatas, maka peneliti mengajukan hipotesis berikut:

$\mathrm{H}_{4}$ :Sosialisasi perpajakan memperkuat pengaruh positif kualitas pelayanan fiskus terhadap kepatuhan wajib pajak

Menurut Prajogo \& Widuri (2013), tingkat pemahaman adalah adalah upaya untuk meningkatkan pengetahuan secara mendalam yang dilakukan oleh seseorang dan sejauh mana ia mampu memahami dengan benar akan suatu permasalahan yang ingin diketahui. Apabila seseorang mempunyai tingkat pemahaman yang baik tentunya akan mudah dia memenuhi kewajiban pajaknya.

Menurut Megawangi \& Setiawan (2017), sosialisasi perpajakan merupakan cara DJP mengarahkan, menginformasikan dan membina masyarakat mengenai hal perpajakan. Bentuk sosialisasi ini bisa melalui media komunikasi, baik media cetak seperti surat kabar, majalah maupun media audio visual seperti radio atau televisi. Adanya sosialisasi perpajakan, akan memberikan kemudahan pemahaman wajib pajak mengenai informasi dan peraturan perpajakan sehingga akan meningkatkan kepatuhan wajib pajak dalam memenuhi kewajiban perpajakannya. Dari uraian diatas, maka dapat dirumuskan hipotesis sebagai berikut :

$\mathrm{H}_{5}$ :Sosialisasi perpajakan memperkuat pengaruh positif pemahaman peraturan perpajakan terhadap kepatuhan wajib pajak

E-filing merupakan bagian dari reformasi administrasi perpajakan dengan tujuan memudahkan dalam membuat dan menyampaikan laporan SPT kepada DJP. Dengan diterapkannya sistem ini, dapat memberikan kepuasan dan kenyamanan kepada wajib pajak sehingga meningkatkan kepatuhan wajib pajak (Husnurrosyidah \& Suhadi, 2017).

Dengan adanya sosialisasi perpajakan yang diberikan oleh Dirjen Pajak mengenai segala sesuatu yang berhubungan dengan peraturan dan perundang - undangan perpajakan. Maka penerapan sistem $e$ filing dapat dilaksanakan lebih mudah dan dipahami oleh wajib pajak. Berdasarkan uraian diatas, maka dapat dirumuskan hipotesis sebagai berikut :

$H_{6}$ :Sosialisasi perpajakan memperkuat pengaruh positif penerapan sistem e-filling terhadap kepatuhan wajib pajak

\section{Metode Penelitian}

Objek yang digunakan dalam penelitian ini adalah Wajib Pajak Orang Pribadi UMKM di Wilayah Kantor Pelayanan Pajak Pratama Pekanbaru Senapelan yang terdaftar berjumlah 4.664 orang pada tahun 2017 sedangkan tahun amatan penelitian tahun 2018. Metode pemilihan sampel yang digunakan peneliti adalah purposive sampling yaitu pengambilan sampel dengan cara menentukan kriteria khusus yang sesuai dengan tujuan penelitian sehingga diharapkan dapat menjawab permasalahan penelitian. Sedangkan untuk menghitung jumlah sampel digunakan rumus Slovin yang biasa digunakan dalam penelitian survey dimana biasanya jumlah sampel besar sekali, sehingga diperlukan sebuah formula untuk mendapatkan sampel yang sedikit tetapi dapat mewakili keseluruhan populasi, rumus Slovin sebagai berikut (Sugiyono, 2014):

$$
n=\frac{N}{1+N(\mathrm{e})^{2}}
$$

Berdasarkan hasil rumus diatas, maka diperoleh sampel dengan batas kesalahan $10 \%$ melalui perhitungan tersebut adalah 97,90 dibulatkan menjadi 100 sampel. Metode Pengumpulan data yang digunakan adalah metode survey dengan cara menyebarkan kuesioner secara langsung kepada responden.

Operasional variabel digunakan untuk menjabarkan variabel penelitian dalam konsep dimensi dan indikator. Indikator-indikator dalam variabel yang telah dijabarkan tersebut dikembangkan menjadi item pertanyaan dalam kuesioner yang menggunakan skala Likert dengan 5 pilihan jawaban, antara lain : Sangat Setuju (SS) skor 5, Setuju (S) skor 4, Netral (N) skor 3, Tidak 


\section{Jurnal Akuntansi dan Pajak, 20(02), 2019, 150}

Setuju (TS) skor 2 dan Sangat Tidak Setuju (STS) skor 1 .

Tabel 3 Pengukuran Variabel

\begin{tabular}{|c|c|c|}
\hline Variabel & Indikator & Kuesioner \\
\hline $\begin{array}{l}\text { Kepatuhan } \\
\text { Wajib Pajak } \\
\text { (Y) }\end{array}$ & $\begin{array}{l}\text { 1. Patuh mendaftarkan diri } \\
\text { memperoleh NPWP } \\
\text { 2. Benar menghitung dan } \\
\text { memperhitungkan pajak } \\
\text { 3. Tepat waktu menyetor } \\
\text { pajak } \\
\text { 4. Tepat waktu } \\
\text { menyampaikan SPT } \\
\text { 5. Patuh membayar } \\
\text { tunggakan pajak beserta } \\
\text { bunganya } \\
\text { (Rahmanto, 2015) }\end{array}$ & 11 petanyaan \\
\hline $\begin{array}{l}\text { Kualitas } \\
\text { Pelayanan } \\
\text { Fiskus }\left(\mathbf{X}_{1}\right)\end{array}$ & $\begin{array}{l}\text { 1. Keandalan (Reliability) } \\
\text { 2. Ketanggapan } \\
\text { (Responsivenes) } \\
\text { 3. Jaminan (Assurance) } \\
\text { 4. Empati (Emphaty) } \\
\text { 5. Bukti Langsung } \\
\text { (Tangibles) } \\
\text { (Artiningsih, 2013) }\end{array}$ & 11 pertanyaan \\
\hline $\begin{array}{l}\text { Pemahaman } \\
\text { Peraturan } \\
\text { Perpajakan } \\
\left(\mathbf{X}_{2}\right)\end{array}$ & $\begin{array}{l}\text { 1. Mengetahui ketentuan } \\
\text { perpajakan yang berlaku } \\
\text { 2. Mengetahui batas waktu } \\
\text { pelaporan SPT } \\
\text { 3. Mengetahui fungsi } \\
\text { NPWP } \\
\text { 4. Mengetahui fungsi } \\
\text { pajak } \\
\text { 5. Memahami sistem } \\
\text { perpajakan saat ini } \\
\text { 6. Tarif pajak yang berlaku } \\
\text { saat ini sudah sesuai } \\
\text { (Rahmanto, 2015) }\end{array}$ & 7 pertanyaan \\
\hline $\begin{array}{l}\text { Penerapan } e \text { - } \\
\text { Filing }\left(\mathbf{X}_{3}\right)\end{array}$ & $\begin{array}{ll}\text { 1. Kecepatan pelaporan } \\
\text { SPT } \\
\text { 2. Penghematan biaya } \\
\text { 3. Kecepatan perhitungan } \\
\text { 4. Memudahkan pengisian } \\
\text { SPT } \\
\text { 5. Meningkatkan kinerja } \\
\text { pelaporan pajak } \\
\text { 6. Kepuasaan penggunaan } \\
\text { (Agustiningsih, 2016) }\end{array}$ & 14 pertanyaan \\
\hline $\begin{array}{l}\text { Sosialisasi } \\
\text { Perpajakan } \\
\text { (Z) }\end{array}$ & $\begin{array}{l}\text { 1. Penyuluhan } \\
\text { 2. Berdiskusi langsung } \\
\text { dengan Wajib Pajak dan } \\
\text { tokoh masyarakat } \\
\text { 3. Informasi langsung dari } \\
\text { fiskus ke Wajib Pajak } \\
\text { 4. Pemasangan billboard } \\
\text { (spanduk, poster, baliho, } \\
\text { dan lain-lain) } \\
\text { 5. Website Ditjen Pajak } \\
\text { (Winerungan, 2013) }\end{array}$ & 5 pertanyaan \\
\hline
\end{tabular}

Metode analisis data dalam penelitian ini adalah Multiple Regression Analysis (Analisis Regresi Berganda). Dipilihnya analisis regresi berganda dalam penelitian ini karena variabel independen dalam penelitian ini lebih dari satu. Berikut ini persamaan analisis regresi berganda untuk menguji hipotesis pertama, kedua dan ketiga adalah sebagai berikut:

$Y=a+\beta_{1} X_{1}+\beta_{2} X_{2}+\beta_{3} X_{3}+\varepsilon$

Selain itu, penelitian ini juga menggunakan Moderated Regression Analyisis (MRA). Analisis regresi ini untuk menjawab hipotesis empat, lima dan enam. Model persamaan MRA yang digunakan (Ghozali, 2012):

$$
\begin{aligned}
Y= & a+\beta_{1} X_{1}+\beta_{2} X_{2}+\beta_{3} X_{3}+\beta_{4} Z+\beta_{5} X_{1} Z+\beta_{6} X_{2} Z+ \\
& \beta_{7} X_{3} Z+\varepsilon
\end{aligned}
$$

\section{Keterangan:}

Y : Kepatuhan Wajib Pajak

a : Konstanta

$\beta_{(1-7)}:$ Koefisien

X1 : Kualitas Pelayanan Fiskus

X2 : Pemahaman Peraturan Perpajakan

X3 : Penerapan Sistem $E$ - Filling

$\mathrm{Z}$ : Sosialisasi Perpajakan

$\varepsilon \quad:$ Error

\begin{tabular}{|c|c|c|c|c|}
\hline Variabel & $\mathbf{T}_{\text {statistik }}$ & $T_{\text {tabel }}$ & Sig. $t$ & Keterangan \\
\hline (Constant) & 1,944 & & 0,055 & \\
\hline $\mathrm{KPF}$ & 0,973 & 1,986 & 0,333 & $\begin{array}{c}\text { Tidak } \\
\text { berpengaruh }\end{array}$ \\
\hline PPP & 0,835 & 1,986 & 0,406 & $\begin{array}{c}\text { Tidak } \\
\text { berpengaruh }\end{array}$ \\
\hline PSE & 6,827 & 1,986 & 0,000 & $\begin{array}{l}\text { Berpengaruh } \\
\text { Positif }\end{array}$ \\
\hline
\end{tabular}

Tabel 4 Hasil Multiple Regression Analysisis

3. Hasil dan Pembahasan

Pada Tabel 4 dapat dilihat $\mathbf{H}_{\mathbf{1}}$ ditolak. Dari hasil pengujian tersebut, maka dapat disimpulkan bahwa kualitas pelayanan fiskus tidak mempengaruhi kepatuhan wajib pajak Orang Pribadi UMKM di KPP Pratama Pekanbaru Senapelan. Kualitas pelayanan adalan ukuran citra yang diakui masyarakat mengenai pelayanan yang diberikan, apakah masyarakat puas atau tidak puas dengan layanan yang diberikan. Hasil penelitian ini sejalan dengan Masruroh \& Zulaikha (2013) menemukan bahwa kepatuhan wajib pajak tidak dipengaruhi oleh kualitas pelayanan fiskus.

Pada Tabel 4 dapat dilihat $\mathbf{H}_{\mathbf{2}}$ ditolak. Hasil pengujian tersebut dapat disimpulkan bahwa pemahaman peraturan perpajakan tidak 


\section{Jurnal Akuntansi dan Pajak, 20(02), 2019, 151}

mempengaruhi kepatuhan wajib pajak Orang Pribadi UMKM di KPP Pratama Pekanbaru Senapelan. Berdasarkan hasil jawaban kuesioner masih ada wajib pajak yang belum memahami ketentuan terkait kewajiban perpajakan yang berlaku. Hasil penelitian ini didukung oleh Prajogo \& Widuri (2013), dan Arisandy (2017) yang menemukan bahwa pemahaman tentang peraturan perpajakan tidak mempengaruhi kepatuhan wajib pajak.

Pada Tabel 4 dapat diketahui $\mathbf{H}_{\mathbf{3}}$ diterima. Dari hasil pengujian tersebut, maka dapat disimpulkan bahwa penerapan sistem $e$-filling berpengaruh positif terhadap kepatuhan wajib pajak Orang Pribadi UMKM di KPP Pratama Pekanbaru Senapelan. Hal ini menunjukkan bahwa semakin baik penerapan sistem e-filling maka kepatuhan wajib pajak akan semakin meningkat. Hasil penelitian ini didukung oleh penelitian Husnurrosyidah \& Suhadi (2017) yang menemukan hasil bahwa penerapan e-filing berpengaruh positif pada kepatuhan wajib pajak.

Tabel 5 Hasil Moderated Regression Analyisis

\begin{tabular}{|c|c|c|c|c|}
\hline Variabel & $\mathbf{T}_{\text {statistik }}$ & $\mathbf{T}_{\text {tabel }}$ & Sig. t & Keterangan \\
\hline $\mathrm{KPF}^{*} \mathrm{Z}$ & 0,607 & 1,986 & 0,545 & $\begin{array}{c}\text { Tidak } \\
\text { memoderasi }\end{array}$ \\
\hline PPP*Z & 0,765 & 1,986 & 0,446 & $\begin{array}{c}\text { Tidak } \\
\text { memoderasi }\end{array}$ \\
\hline PSE*Z & $-1,358$ & 1,986 & 0,178 & $\begin{array}{c}\text { Tidak } \\
\text { memoderasi }\end{array}$ \\
\hline
\end{tabular}

Pada Tabel 5 dapat dilihat $\mathbf{H}_{\mathbf{4}}$ ditolak. Dari hasil pengujian tersebut, maka dapat disimpulkan bahwa sosialisasi perpajakan tidak mampu memoderasi hubungan kualitas pelayanan fiskus terhadap kepatuhan wajib pajak Orang Pribadi UMKM di KPP Pratama Pekanbaru Senapelan. Hasil penelitian ini berbeda dengan penelitian Megawangi \& Setiawan (2017) bahwa sosialisasi perpajakan memperkuat hubungan antara kualitas pelayanan dengan kepatuhan wajib pajak badan.

Pada Tabel 5 dapat dilihat bahwa $\mathbf{H}_{5}$ ditolak. Dari hasil pengujian tersebut, maka dapat disimpulkan bahwa sosialisasi perpajakan belum mampu memoderasi hubungan antara pemahaman peraturan perpajakan terhadap kepatuhan wajib pajak Orang Pribadi UMKM di KPP Pratama Pekanbaru Senapelan. Artinya, walaupun pihak fiskus telah melakukan sosialisasi mengenai perpajakan belum mendukung pemahaman wajib pajak tentang peraturan perpajakan yang berlaku serta penerapannya sehingga tidak mempengaruhi kepatuhan wajib pajak.
Pada Tabel 5 dapat dilihat bahwa $\mathbf{H}_{\mathbf{6}}$ ditolak. Dari hasil pengujian tersebut, maka dapat disimpulkan bahwa sosialisasi perpajakan belum mampu memoderasi pengaruh penerapan e-filling terhadap kepatuhan wajib pajak Orang Pribadi UMKM di KPP Pratama Pekanbaru Senapelan. Temuan ini sejalan dengan penelitian yang dilakukan oleh Handayani dan Tambun (2016) yang menyatakan bahwa sosialisasi perpajakan tidak mampu memoderasi penerapan sistem e-filling terhadap kepatuhan wajib pajak.

\section{Kesimpulan}

Penelitian ini dilakukan untuk mengetahui dan menguji kualitas pelayanan fiskus, pemahaman peraturan perpajakan dan penerapan sistem $e$-filling terhadap kepatuhan wajib pajak dengan sosialisasi perpajakan sebagai variabel pemoderasi. Penelitian ini menemukan bahwa kualitas pelayanan fiskus dan pemahaman peraturan perpajakan secara parsial tidak mempengaruhi kepatuhan wajib pajak, namun penerapan sistem $e$-filling memiliki pengaruh positif pada kepatuhan wajib pajak. Selain itu, sosialisasi perpajakan bukan sebagai variabel pemoderasi antara pengaruh kualitas pelayanan fiskus, pemahaman peraturan perpajakan, dan penerapan sistem $e$-filling terhadap kepatuhan wajib pajak.

Penelitian ini masih memiliki keterbatasan. Pertama, Adanya kendala dalam pengumpulan data menggunakan metode survey berbasis kuesioner yaitu dikhawatirkan responden menjawab pertanyaan survei secara normatif karena tema penelitian bersifat sensitif sehingga kemungkinan hasil penelitian bias dengan kondisi yang sebenarnya di lapangan. Kedua, responden hanyalah Wajib Pajak Orang Pribadi UMKM wilayah KPP Pratama Pekanbaru Senapelan sehingga hasil penelitian belum tentu sesuai untuk digeneralisasikan pada Wajib Pajak Orang Pribadi UMKM di luar wilayah KPP Pratama Pekanbaru Senapelan. Oleh karena itu, saran untuk pengembangan dari penulis, yaitu: Pertama, penelitian selanjutnya dapat mencari dan menambah variabel-variabel lain yang diduga mempengaruhi kepatuhan wajib pajak. Kedua, perlu dilakukan wawancara yang mungkin dapat membantu dalam mengendalikan jawaban tiap responden dan menghindari metode pengumpulan data yang memungkinkan munculnya selection bias. Ketiga, peneliti selanjutnya dapat memperluas objek penelitian sehingga hasil penelitian dapat digeneralisasikan. Keempat, penelitian selanjutnya 


\section{Jurnal Akuntansi dan Pajak, 20(02), 2019, 152}

dapat menggunakan teknik metode sampling yang lain dalam pengambilan sampel sehingga hasilnya lebih akurat.

\section{Daftar Pustaka}

Adiasa, N. (2013). Pengaruh Pemahaman Peraturan Pajak Terhadap Kepatuhan Wajib Pajak Dengan Moderating Preferensi Risiko. Accounting Analysis Journal, 2(3), 345-352. https://doi.org/10.15294/aaj.v2i3.2848

Arisandy, N. (2017). Pengaruh Pemahaman Wajib Pajak, Kesadaran Wajib Pajak Dan Sanksi Pajak Terhadap Kepatuhan Wajib Pajak Orang Pribadi Yang Melakukan Kegiatan Bisnis Online Di Pekanbaru. Jurnal Ilmiah Ekonomi Dan Bisnis, 14(1), 62-71.

Artiningsih. (2013). Pengaruh Kesadaran Wajib Pajak Badan dan Pelayanan Perpajakan Terhadap Kepatuhan Wajib Pajak di KPP Pratama Sleman. Skripsi. Fakultas Ekonomi Universitas Negeri Yogyakarta.

Dharma, G. P. E., \& Suardana, K. A. (2014). Pengaruh Kesadaran Wajib Pajak, Sosialisasi Perpajakan, Kualitas Pelayanan Pada Kepatuhan Wajib Pajak. E-Jurnal Akuntansi Universitas Udayana, 6(1), 340-353.

Dwikora, H. (2013). Perpajakan Indonesia. Jakarta: Mitra Wacana Media.

Erawati, T., \& Ratnasari, R. (2018). Pengaruh Penerapan E-filing Terhadap Kepatuhan Wajib Pajak Dalam Menyampaikan SPT Tahunan Dengan Kepuasan Kualitas Pelayanan Sebagai Variabel Intervening. Jurnal Akuntansi, 6(1), 1-10. https://doi.org/10.24964/ja.v6i1.427

Fuadi, A. O., \& Mangoting, Y. (2013). Pengaruh Kualitas Pelayanan, Sanksi Perpajakan Dan Biaya Kepatuhan Terhadap Kepatuhan Wajib Pajak UMKM. Tax \& Accounting Review, 1(1), 18-27.

Handayani, K. R., \& Tambun, S. (2016). Pengaruh Penerapan Sistem E-Filling dan Pengetahuan Perpajakan Terhadap Kepatuhan Wajib Dengan Sosialisasi Sebagai Variabel Moderating. Media Akuntansi Perpajakan, 1(2), 59-73.

Husnurrosyidah, \& Suhadi. (2017). Pengaruh EFiling, e-Billing dan e-Faktur Terhadap Kepatuhan Pajak pada BMT Se-Kabupaten Kudus. Jurnal Analisa Akuntansi Dan Perpajakan, 1(1), 97-106.
Jatmiko, A. N. (2006). Pengaruh Sikap Wajib Pajak pada Pelaksanaan Sanksi Denda, Pelayanan Fiskus, dan Kesadaran Perpajakan Terhadap Kepatuhan Wajib Pajak Studi Empiris Terhadap Wajib Pajak Orang Pribadi di Kota Semarang. Tesis. Magister Akuntansi Unisversitas Diponegoro.

Masruroh, S., \& Zulaikha. (2013). Pengaruh Kemanfaatan NPWP, Pemahaman Wajib Pajak, Kualitas Pelayanan, Sanksi Perpajakan, Terhadap Kepatuhan Wajib Pajak. Diponegoro Journal of Accounting, 2(4), 1-15.

Megawangi, C. A. M., \& Setiawan, P. E. (2017). Sosialisasi Perpajakan Memoderasi Pengaruh Kesadaran Wajib Pajak Dan Kualitas Pelayanan Pada Kepatuhan Wajib Pajak Badan. E-Jurnal Akuntansi Universitas Udayana, 19(3), 23482377.

Prajogo, J. N., \& Widuri, R. (2013). Pengaruh Tingkat Pemahaman Peraturan Pajak Wajib Pajak, Kualitas Pelayanan Petugas Pajak, dan Persepsi Atas Sanksi Perpajakan Terhadap Kepatuhan Wajib Pajak UMKM di Wilayah Sidoarjo. Tax \& Accounting Review, 3(2), 1-12. Rahayu, N. (2017). Pengaruh Pengetahuan Perpajakan, Ketegasan Sanksi Pajak, dan Tax Amnesty Terhadap Kepatuhan Wajib Pajak. Jurnal Akuntansi Dewantara. Akunansi Dewantara, 1(1), 15-29. https://doi.org/10.29230/ad.v1i1.21

Rahayu, S. K., \& Suhayati, E. (2010). Perpajakan, Teori, dan Teknis Perhitungan. Yogyakarta: Graha Ilmu.

Rahmanto, B. W. (2015). Pengaruh Pemahaman Peraturan Pajak, Sanksi Denda, dan Kesadaran Wajib Pajak, terhadap Kepatuhan Wajib Pajak Orang Pribadi di Kantor Pelayanan Pajak Pratama Yogyakarta Pada Tahun 2014. In Skripsi. Universitas Negeri Yogyakarta.

Resmi, S. (2012). Perpajakan Teori dan Kasus. Jakarta: Salemba Empat.

Resmi, S. (2017). Perpajakan: Teori dan Kasus (10th ed.). Jakarta: Salemba Empat.

Siregar, Y. A., Saryadi., \& Listyorini, S. (2012). Pengaruh Pelayanan Fiskus dan Pengetahuan Perpajakan Terhadap Kepatuhan Wajib Pajak (Studi Empiris terhadap Wajib Pajak di Semarang Tengah). Julnal Ilmu Administrasi Bisnis, 1(1), 1-9. 


\section{Jurnal Akuntansi dan Pajak, 20(02), 2019, 153}

Sugiyono. (2014). Metode Penelitian Bisnis (Pendekatan Kuantitatif, Kualitatif, Dan R\&D). Bandung: CV Alfabeta.

Suherman, M., Almunawwaroh, M., \& Marliana, R. (2015). Pengaruh Penerapan E-Filing Terhadap Kepatuhan Wajib Pajak Dalam Penyampaian Surat Pemberitahuan (SPT) Tahunan Pada Kantor Pelayanan Pajak Pratama Kota Tasikmalaya. Media Riset Akuntansi, Auditing \& Informasi, 15(1), 49-64.

Supadmi, N. L. (2009). Meningkatkan Kepatuhan Wajib Pajak Melalui Kualitas Pelayanan. Jurnal Ilmiah Akuntansi Dan Bisnis, 4(2), 1-14. Suryadi, I., \& Sunarti. (2016). Pengaruh Sosialisasi Perpajakan, Sanksi Administrasi dan Tingkat Pemahaman Wajib Pajak terhadap Kepatuhan Wajib Pajak Orang Pribadi dalam Memenuhi Kewajibannya (Studi PPh Pasal 21 pada KPP Pratama Singsosari). Jurnal Perpajakan (JEJAK), 8(1), 1-10.
Susmita, P. R., \& Supadmi, N. L. (2016). Pengaruh Kualitas Pelayanan, Sanksi Perpajakan, Biaya Kepatuhan Pajak, dan Penerapan e-Filing Pada Kepatuhan Wajib Pajak. E-Journal Akuntansi Universitas Udayana, 14(2), 1239-1269.

Winerungan, O. L. (2013). Sosialisasi Perpajakan, Pelayanan Fiskus dan Sanksi Perpajakan Terhadap Kepatuhan WPOP di KPP Manado dan KPP Blitung. Jurnal EMBA: Jurnal Riset Ekonomi, Manajemen, Bisnis, Dan Akuntansi, 1(3), 960-970. 